\title{
Origin of the supergiant Olympic Dam Cu-U-Au-Ag deposit, South Australia: Was a sedimentary basin involved?
}

\author{
Jocelyn McPhie ${ }^{1}$, Vadim S. Kamenetsky ${ }^{1}$, Isabelle Chambefort ${ }^{1}$, Kathy Ehrig ${ }^{2}$, and Nicholas Green ${ }^{2}$ \\ ${ }^{1}$ ARC Centre of Excellence in Ore Deposits, and School of Earth Sciences, University of Tasmania, Hobart, Tasmania 7001, Australia \\ 2BHP-Billiton, GPO Box 1777, Adelaide, South Australia 5001, Australia
}

\begin{abstract}
The supergiant Olympic Dam Cu-U-Au-Ag ore deposit of South Australia occurs in a tectonic-hydrothermal breccia complex that is surrounded by Mesoproterozoic granite. The breccia is composed mainly of granite clasts and minor amounts of Mesoproterozoic volcanic clasts. Very thick $(>350 \mathrm{~m})$ sections of bedded sedimentary facies that occur in the breccia complex include laminated to very thin planar mudstone beds, thin to medium internally graded sandstone beds, and thick conglomerate beds. The bedded sedimentary facies extend continuously across a $1.5 \mathrm{~km} \times 0.9 \mathrm{~km}$ area and are not limited to small separate maar craters, as previously thought. Detrital chromite and volcanic quartz in the bedded sedimentary facies cannot be matched with local sources, and imply that the provenance extended beyond the area of Olympic Dam. The lateral continuity, provenance characteristics, great thickness, below-wave-base lithofacies, and intracontinental setting suggest that the bedded sedimentary facies are remnants of a sedimentary basin that was present at Olympic Dam prior to formation of the breccia complex. We conclude that the Olympic Dam hydrothermal system operated beneath and partly within an active sedimentary basin, was not confined to maar craters, and did not vent. This new view of the setting raises the possibility that sedimentary processes were involved in ore genesis.
\end{abstract}

\section{INTRODUCTION}

Olympic Dam (OD) is a supergiant $\mathrm{Cu}-$ U-Au-Ag ore deposit $\left(\sim 9 \times 10^{9} \mathrm{t}\right)$ hosted by hematite-rich breccia within a Mesoproterozoic granite in South Australia (Fig. 1A). It was discovered using an exploration model developed for sediment-hosted stratabound $\mathrm{Cu}$ deposits, and initially interpreted to be a variety of sediment-hosted mineralization (Roberts and Hudson, 1983). Subsequent publications have favored a magmatic-hydrothermal origin (e.g., Reeve et al., 1990; Oreskes and Einaudi, 1992, 1990; Johnson and Cross, 1995). Furthermore, Reeve et al. (1990) proposed that the magmatic-hydrothermal activity was focused within multiple mafic maar-diatreme volcanoes and that the hydrothermal system vented by means of hydrothermal explosions and fumaroles. The maar-diatreme setting of the OD hydrothermal system has influenced interpretations of the fluid compositions and sources, metal sources, and the age of the deposit (e.g., Haynes et al., 1995; Johnson and Cross, 1995; Skirrow et al., 2007).

The maar-diatreme setting of OD (Reeve et al., 1990; Johnson and Cross, 1995) was based on: (1) the recognition of five apparently isolated domains of bedded clastic facies that were interpreted to consist in part of "reworked hydrothermal eruption breccias" (Reeve et al., 1990, p. 1033) in diatremes; (2) the downward-tapering shape of one of the domains, taken to represent a former conduit for explosive eruptions; and (3) the presence of mafic dikes that were interpreted to be feeders to phreatomagmatic eruptions.

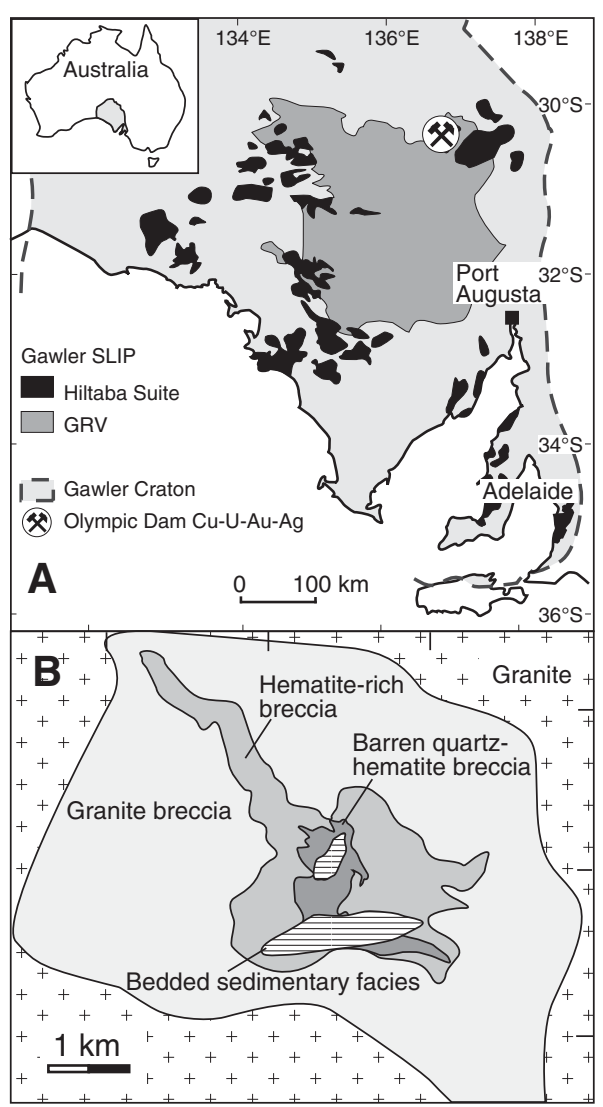

Figure 1. A: Location of Olympic Dam in northeastern part of Gawler silicic large igneous province (SLIP). GRV-Gawler Range Volcanics. B: Map of Olympic Dam breccia complex at $\sim 500 \mathrm{~m}$ below surface.
Exploration drilling in the past $10 \mathrm{yr}(626 \mathrm{~km}$ of diamond drill core) has greatly extended our knowledge of the architecture of the host succession. Here we propose an alternative to the widely accepted maar-diatreme setting of ore formation. We suggest that OD formed beneath and partly within a sedimentary basin. Our new view of the architecture of OD has major implications for the genesis of this ore body and others like it.

\section{OLYMPIC DAM ORE DEPOSIT}

The OD ore deposit is the world's largest uranium deposit, and fourth largest in gold and copper; it is also rich in rare earth elements, fluorine, and iron (Oreskes and Einaudi, 1990; Reeve et al., 1990). The principal ore minerals are $\mathrm{Cu}$ sulfides and U oxides (Roberts and Hudson, 1983). There is a deposit-wide zonation in the sulfide minerals, from chalcocite and bornite at shallow levels, to chalcopyrite and pyrite at deeper levels (Roberts and Hudson, 1983; Reeve et al., 1990).

The ore minerals occur in hematite-rich breccia that is part of the larger OD breccia complex (Reeve et al., 1990; Fig. 1B). The breccia complex is totally surrounded by the Roxby Downs Granite (ca. $1588 \mathrm{Ma}$; Creaser and Cooper, 1993). This granite belongs to the Hiltaba Suite (ca. 1598-1583 Ma), which, together with the Gawler Range Volcanics (GRV) (ca. $1590 \mathrm{Ma}$ ), constitutes the Gawler silicic large igneous province (SLIP; Fanning et al., 1988; Flint, 1993; Allen et al., 2008). The Gawler SLIP is unmetamorphosed and largely undeformed, in contrast to the underlying Paleoproterozoic and Archean rocks of the Gawler craton. The ore body and the host succession are unconformably overlain by unmineralized late Neoproterozoic formations that are at least $250 \mathrm{~m}$ thick (Reeve et al., 1990).

\section{OLYMPIC DAM BRECCIA COMPLEX}

The OD breccia complex consists of hematiterich breccia, granite breccia, quartz-hematite breccia, and bedded sedimentary facies, all of which are crosscut by mafic dikes. The hematite-rich breccia is mineralized and occupies a central domain within largely barren, nonstratified, monomictic, granite breccia that has gradational contacts with intact Roxby Downs Granite (Fig. 1B). The hematite-rich breccia locally includes domains of polymictic volcanic breccia mainly composed of feldspar-phyric 
felsic volcanic clasts, and a small proportion $(<1 \%-2 \%)$ of bedded fine sandstone clasts (Fig. 2A). The texture, contact relationships, distribution, and nonstratified character of breccias in the OD breccia complex are consistent with subsurface fragmentation involving a combination of tectonic and hydrothermal processes
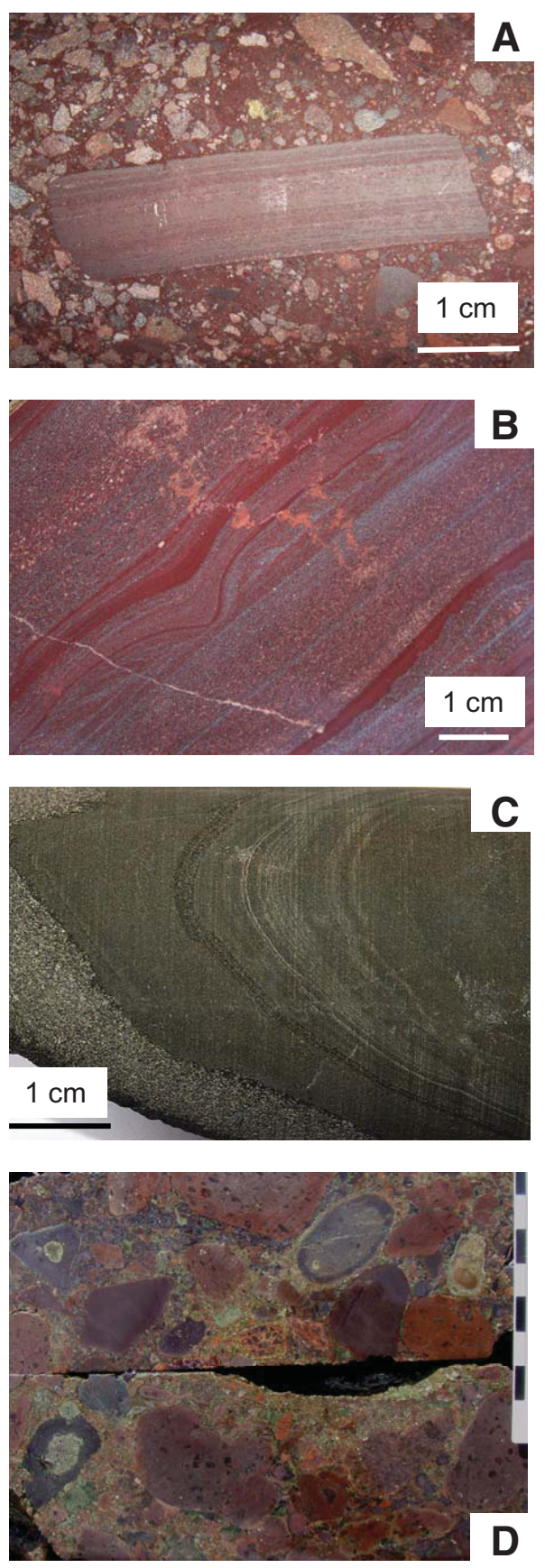

Figure 2. A: Clast of laminated hematite-rich sandstone in hematite-rich breccia, RD3008, $722.2 \mathrm{~m}$. B: Laminated hematite-rich mudstone and sandstone in bedded sedimentary facies, RD3287, $355.3 \mathrm{~m}$. C: Laminated chlorite-rich mudstone and sandstone, RD1989, 422.1 m. D: Polymictic volcanic conglomerate, RD3449, $414 \mathrm{~m}$. Scale bar increments are in centimeters.
(Oreskes and Einaudi, 1990; Reeve et al., 1990). Angular or ragged, amoeboid, and digitate clast shapes suggest that both brittle failure and dissolution of preexisting wall rock (mainly Roxby Downs Granite and GRV) were important.

\section{BEDDED SEDIMENTARY FACIES}

The OD breccia complex includes intervals of bedded sedimentary facies as much as $350 \mathrm{~m}$ thick immediately below the unconformity with the late Neoproterozoic formations. The largest occurrence of the bedded sedimentary facies is at least $\sim 1.5 \mathrm{~km} \times 0.9 \mathrm{~km}$, and encompasses four of the five so-called diatreme structures of Reeve et al. (1990). Contacts with the hematiterich breccia are gradational or faulted. At gradational contacts, bedded sedimentary clasts occur dispersed within the hematite-rich breccia and/ or domains of hematite-rich breccia cut across the bedded sedimentary facies.

The bedded sedimentary facies consist of laminated to very thinly bedded mudstone, thinly to medium-bedded sandstone, and thickly bedded conglomerate (Figs. 2B-2D). Both red, hematite-rich and green, chlorite-rich mudstone-sandstone intervals occur and can be tens of meters thick. The sandstone beds are internally graded or massive. Sandstone in the red, hematite-rich intervals contains abundant granite fragments and granite-derived feldspar and quartz. Sandstone in the green, chloriterich intervals mainly consists of mafic volcanic fragments and also contains detrital chromite. Volcanic quartz ( $<5$ modal $\%$ ) is present in most examples of both red and green sandstone; these quartz grains are clear, have straight extinction, and contain glassy inclusions. The conglomerate beds consist of well-rounded, moderately sorted, feldspar-phyric felsic and mafic volcanic clasts and minor granite clasts. Some intervals of the bedded sedimentary facies have been affected by soft-sediment deformation that produced short-wavelength (decimeter scale) disharmonic folds, changes in dip, and intraformational faults.

\section{DISCUSSION}

Provenance of the Bedded Sedimentary Facies

Components in the bedded sedimentary facies reflect a provenance dominated by the Gawler SLIP that covered at least 70,000 $\mathrm{km}^{2}$ of the Gawler craton, including the OD area, in the Mesoproterozoic (Allen et al., 2008). The source of granitic components could have been unroofed Hiltaba Suite granites, possibly including the Roxby Downs Granite. The source of the volcanic components was the GRV. The feldspar-phyric felsic volcanic clasts are texturally, mineralogically, and compositionally identical to extensive felsic lavas in the GRV exposed $\sim 150 \mathrm{~km}$ west of OD (Allen et al., 2008) and found in drill core nearby ( $>400 \mathrm{~m}$ of feldsparphyric felsic lava, $20 \mathrm{~km}$ southwest of OD). Mafic volcanic units are present throughout the GRV, though subordinate to the felsic units, and also occur in drill core close to OD ( $>350 \mathrm{~m}$ of basaltic lava, $\sim 15 \mathrm{~km}$ northeast of OD).

The components discussed so far could have had very local (less than a few kilometers) and/ or remote sources because the Gawler SLIP was regionally extensive. However, two components imply that the provenance of the bedded sedimentary facies included sources outside the immediate OD area. One is the chromite found in the green, chlorite-rich sandstone. The octahedral chromite grains have a wide range of compositions, even within single samples of the green chlorite-rich sandstone (Figs. 3A and 3B). The least-altered grains (based on $\mathrm{Mg \#}>0.3, \mathrm{MgO}>6 \mathrm{wt} \%$, and $\mathrm{ZnO}<0.15$ wt\%) vary significantly in $\mathrm{Cr} \#$ at a given $\mathrm{Mg \#}$ (up to 0.35 ; Fig. 3A). Such variation indicates variable magma composition and crystallization conditions (e.g., Irvine, 1967; Arai, 1992). Similarly, $\mathrm{TiO}_{2}$ and $\mathrm{Al}_{2} \mathrm{O}_{3}$ contents of detrital chromite (Fig. 3B) reflect substantial variations in the composition of parental melts (0.3-1.0 wt $\%$ and 9.5-13.5 wt\%, respectively, according to the empirical calibration of Kamenetsky et al., 2001). In general, low-Ti and low-Al/ high-Cr\# compositions of volcanic Cr-spinel originate from magmas associated with subduction (e.g., Arai, 1992; Kamenetsky et al., 2001). No chromite-bearing mafic lavas of appropriate composition have been identified in the vicinity of OD. Moreover, the range of compositions of the chromite grains in OD sandstones is notably wider than in Phanerozoic subduction-related volcanic suites (Fig. 3B). We conclude that the chromite grains were derived from separate volcanic sources and mixed by surface processes prior to final deposition. The enrichment of $\mathrm{Cr}$ in sandstone (Fig. 3C) reflects concentration of chromite that is also easily explained by conventional sedimentary processes.

The second component that cannot be linked to a local GRV source is volcanic quartz. Quartz-bearing volcanic units occur in the GRV exposed to the west of OD (Allen et al., 2008). However, quartz crystals and/or phenocrysts have not been reported in the GRV intersected in drill core near OD (Creaser, 1989), and the felsic volcanic clasts in the hematite-rich breccia at OD are not quartz-phyric.

\section{Olympic Dam Sedimentary Basin}

The bedded sedimentary facies indicate the former presence of a depocenter at OD in which laminated mud and graded sand beds typical of below-wave-base subaqueous settings accumulated. Conglomerate beds are likely to be deposits from high-concentration sediment gravity currents (debris flows and turbidity currents). 

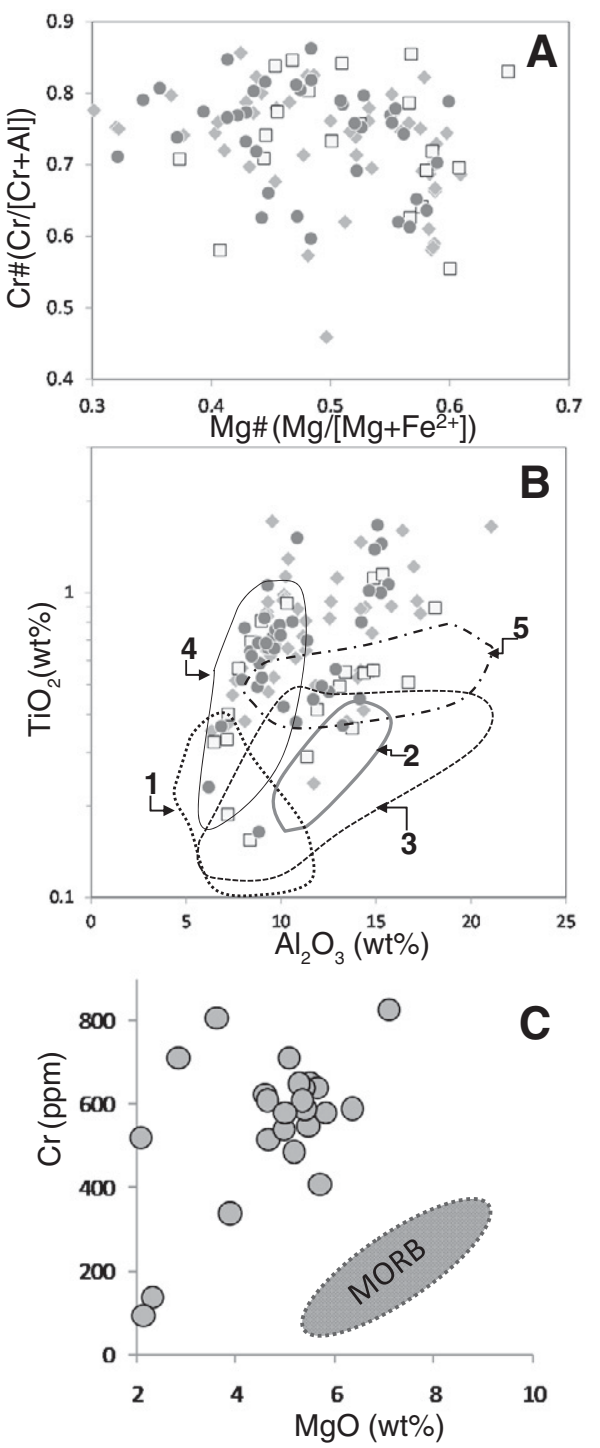

Figure 3. A, B: Compositions of chromite grains in three samples of green, chloriterich sandstone (each symbol denotes different sample), analyzed by Cameca SX100 electron microprobe (University of Tasmania). B shows fields for Cr-spinel compositions typical of subduction-related volcanic rocks (after Kamenetsky et al., 2001). 1Southwest Pacific high-Ca boninites (New Caledonia and Hunter Ridge); 2-Troodos, Cyprus, high-Ca boninites; 3-island-arc tholeiites from Hunter Ridge and Hunter Fracture Zone; 4-high-K picrites from eastern Kamchatka; 5-alkaline primitive magmas of Roman comagmatic province. C: Cr enrichment in Olympic Dam chromitebearing sandstone samples in comparison to mid-oceanic ridge basalt (MORB) glasses.

The preserved sections suggest that the uncompacted sediment thickness was $>500 \mathrm{~m}$.

We propose that the OD depocenter was part of a sedimentary basin that extended beyond the OD area and was not limited to local maar craters (cf. Reeve et al., 1990; Johnson and Cross, 1995), because this interpretation is consistent with the provenance characteristics, the distinct and sustained shifts in provenance, the belowwave-base sedimentation style, and the intracontinental setting. Four of the five domains of bedded sedimentary facies interpreted to be maar crater-fill sediments (Reeve et al., 1990) are now known to be connected and do not represent conduits. Sedimentation restricted to small (typically $<1000 \mathrm{~m}$ diameter; Pike and Clow, 1981) closed maar craters does not explain the marked concentration of chromite in some sandstone samples (Fig. 3C) or the wide range of chromite compositions (Figs. 3A and 3B). Such a setting does not adequately account for the well-rounded shapes of pebbles in the conglomerate that reflect reworking in a highenergy environment prior to final deposition, and components from the different sources are not well mixed, as would be expected. In addition, there is no known local source of volcanic quartz. The coherent and brecciated mafic dikes that were thought to be feeders to phreatomagmatic eruptions intrude, and therefore postdate, the bedded sedimentary facies.

The dimensions of the OD sedimentary basin are unknown. However, the dominance of subaqueous below-wave-base facies, substantial thickness, and presence of exotic components imply that the basin was much more extensive than the bedded sedimentary facies preserved at OD.

\section{Setting of the Olympic Dam Hydrothermal System}

Our interpretation of the bedded sedimentary facies as remnants of a sedimentary basin underpins our reconstruction of the original architecture of the succession (Fig. 4A). The Roxby Downs Granite was surrounded by Paleoproterozoic country rock and overlain by lavas of the GRV. These units were overlain by a sedimentary succession, remnants of which are preserved as the bedded sedimentary facies.

Regional faults were instrumental in the formation of the OD breccia complex, being the sites where subsurface tectonic brecciation was initiated and then evolved into tectonichydrothermal brecciation (Reeve et al., 1990). We infer that the same faults initiated and partly defined the OD sedimentary basin. The presence of deformed but nearly intact, very thick intervals of bedded sedimentary facies at the top of the breccia complex suggests that tectonichydrothermal fragmentation propagated from a deeper site in the Roxby Downs Granite upward into the GRV and the bedded sedimentary facies (Fig. 4B). Multiple mafic dikes intruded the Roxby Downs Granite and the OD breccia complex, including the bedded sedimentary facies (Fig. 4C). They could be delineating the positions of the early faults that controlled initial tectonic fragmentation, because in some cases
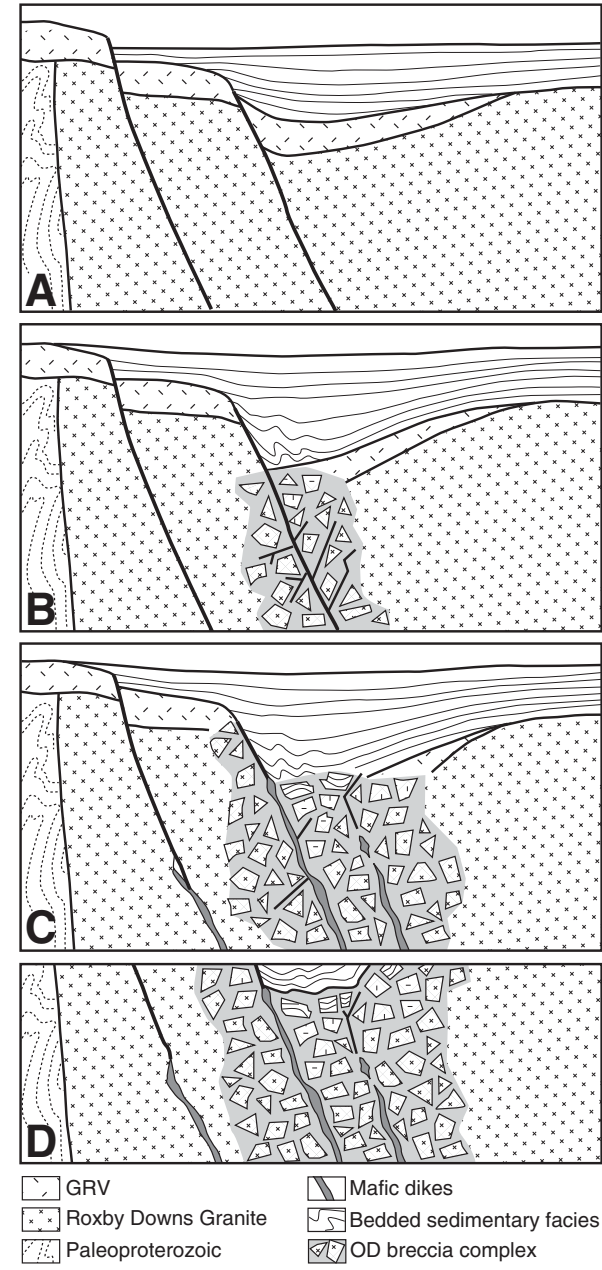

Figure 4. A: Bedded sedimentary facies accumulated in fault-bound basin above Mesoproterozoic granite and lavas. B: Faultcontrolled subsurface fragmentation of Roxby Downs Granite, Gawler Range Volcanics (GRV) lavas, and bedded sedimentary facies formed Olympic Dam (OD) breccia complex. C: Mafic dikes intruded granite and breccia complex along faults. D: Erosion unroofed breccia complex, removing almost all traces of bedded sedimentary facies.

they have been intensely sheared and brecciated where faults have been reactivated after dike emplacement. There is no evidence in the preserved sections that the OD hydrothermal system breached the surface in the form of hydrothermal or phreatomagmatic eruptions (cf. Reeve et al., 1990). Instead, the hydrothermal system operated beneath and within the thick cover of bedded sediment.

Erosion in the period following ore formation exhumed the OD breccia complex, and removed almost all of the sedimentary facies that existed at OD (Fig. 4D).

The previous idea of a maar-diatreme setting for the OD hydrothermal system has underpinned ore genesis models for OD and for the entire $\mathrm{Fe}$ oxide- $\mathrm{Cu}-\mathrm{Au}$ ore deposit class of 
which OD is the type (Hitzman et al., 1992), and implies a strong link to Gawler SLIP magmas as fluid and metal sources. Our new view raises the possibility that sedimentary influences were important. In particular, the OD hydrothermal system would have had access to and interacted with the overlying sedimentary succession, so this succession should be considered as an additional source of both fluids and metals. The OD breccia complex contains a small proportion of intact sedimentary clasts, but the total proportion of components derived from the sedimentary succession could be much larger, because the relatively soft sedimentary facies would have disintegrated completely during fragmentation, contributing to the overall matrix-rich, relatively fine grained character of the OD hydrothermal breccias. The confinement of the hydrothermal system beneath and partly within the flat-lying sedimentary succession helps to explain the subhorizontal orientation of the $\mathrm{Cu}$ sulfide zones at $\mathrm{OD}$.

\section{Age of the Olympic Dam Sedimentary Basin}

The bedded sedimentary facies contain components derived from the Gawler SLIP and are therefore ca. $1590 \mathrm{Ma}$ or younger. They were present during formation of the OD breccia complex and ore deposition because they are hydrothermally altered and mineralized, and clasts of the bedded sedimentary facies occur in the breccia complex. An upper limit on their age is provided by the crosscutting mafic dikes, one set of which was intruded ca. $800 \mathrm{Ma}$ (Zhao and McCulloch, 1993).

\section{CONCLUSIONS}

Bedded sedimentary facies within the OD breccia complex are here interpreted to be remnants of a sedimentary basin succession. This interpretation is based on the continuity of the bedded sedimentary facies, and their regional provenance, facies characteristics, and large thickness. The sedimentary basin covered the OD area prior to formation of the breccia complex that hosts the ore body. The OD breccia complex formed by multiple episodes of faultcontrolled, subsurface fragmentation of granite wall rock that propagated into overlying GRV lavas and bedded sedimentary facies but did not breach the surface. Although the OD breccia complex and ore body are primarily hydro- thermal in origin, the OD hydrothermal system would have had access to and interacted with the overlying sedimentary succession.

\section{ACKNOWLEDGMENTS}

This project was funded by the Australian Research Council and BHP Billiton. Discussions with S. Meffre, R. Large, and K. Cross are gratefully acknowledged. Analyses were obtained with the help of Karsten Goemann. We thank six anonymous referees, Pablo Dávila Harris, Poul Emsbo, and Bill Collins for comments on a previous manuscript.

\section{REFERENCES CITED}

Allen, S.R., McPhie, J., Ferris, G., and Simpson, C., 2008, Evolution and architecture of a large felsic igneous province in western Laurentia: The 1.6 Ga Gawler Range Volcanics, South Australia: Journal of Volcanology and Geothermal Research, v. 172 , p. $132-147$, doi:10.1016/j .jvolgeores.2005.09.027.

Arai, S., 1992, Chemistry of chromian spinel in volcanic rocks as a potential guide to magma chemistry: Mineralogical Magazine, v. 56, p. 173-184.

Creaser, R.A., 1989, The geology and petrology of Middle Proterozoic felsic magmatism of the Stuart Shelf, South Australia [Ph.D. thesis]: Canberra, Australia, Australian National University, $434 \mathrm{p}$.

Creaser, R.A., and Cooper, J.A., 1993, U-Pb geochronology of middle Proterozoic felsic magmatism surrounding the Olympic Dam $\mathrm{Cu}-\mathrm{Au}$ $\mathrm{U}-\mathrm{Ag}$ and Moonta $\mathrm{Cu}-\mathrm{Au}-\mathrm{Ag}$ deposits, South Australia: Economic Geology and the Bulletin of the Society of Economic Geologists, v. 88, p. 186-197, doi:10.2113/gsecongeo.88.1.186.

Fanning, C.M., Blissett, R.B., Parker, A.J., Ludwig, K.R., and Blissett, A.H., 1988, Refined Proterozoic evolution of the Gawler Craton, South Australia, through U-Pb geochronology: Precambrian Research, v. 40-41, p. 363-386, doi:10.1016/0301-9268(88)90076-9.

Flint, R.B., 1993, Mesoproterozoic, in Drexel, J.F., et al., eds., The geology of South Australia, Volume 1: The Precambrian: Geological Survey of South Australia Bulletin, v. 54, p. 107-169.

Haynes, D.W., Cross, K.C., Bills, R.T., and Reed, M.H., 1995, Olympic Dam ore genesis: A fluid mixing model: Economic Geology and the Bulletin of the Society of Economic Geologists, v. 90, p. 281-307, doi:10.2113/gsecongeo.90.2.281.

Hitzman, M.W., Oreskes, N., and Einaudi, M.T., 1992, Geological characteristics and tectonic setting of Proterozoic iron oxide (Cu-U-Au-LREE) deposits: Precambrian Research, v. 58, p. 241287, doi:10.1016/0301-9268(92)90121-4.

Irvine, T.N., 1967, Chromian spinel as a petrogenetic indicator. Part 2. Petrologic applications: Canadian Journal of Earth Sciences, v. 4, p. 71-103, doi:10.1139/e67-004.

Johnson, J.P., and Cross, K.C., 1995, U-Pb geochronological constraints on the genesis of the
Olympic Dam Cu-U-Au-Ag deposit, South Australia: Economic Geology and the Bulletin of the Society of Economic Geologists, v. 90, p. 10461063, doi:10.2113/gsecongeo.90.5.1046.

Kamenetsky, V.S., Crawford, A.J., and Meffre, S., 2001, Factors controlling chemistry of magmatic spinel: An empirical study of associated olivine, Cr-spinel and melt inclusions from primitive rocks: Journal of Petrology, v. 42, p. 655-671, doi:10.1093/petrology/42.4.655.

Oreskes, N., and Einaudi, M.T., 1990, Origin of rare earth element-enriched hematite breccias at the Olympic Dam $\mathrm{Cu}-\mathrm{U}-\mathrm{Au}-\mathrm{Ag}$ deposit, Roxby Downs, South Australia: Economic Geology and the Bulletin of the Society of Economic Geologists, v. 85, p. 1-28, doi:10.2113/ gsecongeo.85.1.1.

Oreskes, N., and Einaudi, M.T., 1992, Origin of hydrothermal fluids at Olympic Dam: Preliminary results from fluid inclusions and stable isotopes: Economic Geology and the Bulletin of the Society of Economic Geologists, v. 87, p. 64-90, doi:10.2113/gsecongeo.87.1.64.

Pike, R.J., and Clow, G.D., 1981, Revised classification of terrestrial volcanoes and catalog of topographic dimensions, with new results on edifice volume: U.S. Geological Survey OpenFile Report 81-1038, $40 \mathrm{p}$.

Reeve, J.S., Cross, K.C., Smith, R.N., and Oreskes, N., 1990, Olympic Dam copper-uranium-goldsilver deposit, in Hughes, F.E., ed., Geology of the mineral deposits of Australia and Papua New Guinea: Melbourne, Australia, Australian Institute of Mining and Metallurgy, p. 1009-1035.

Roberts, D.E., and Hudson, G.R.T., 1983, The Olympic Dam copper-uranium-gold deposit, Roxby Downs, South-Australia: Economic Geology and the Bulletin of the Society of Economic Geologists, v. 78, p. 799-822, doi:10.2113/ gsecongeo.78.5.799.

Skirrow, R.G., Bastrakov, E.N., Barovich, K., Fraser, G.L., Creaser, R.A., Fanning, C.M., Raymond, O.L., and Davidson, G.J., 2007, Timing of iron oxide $\mathrm{Cu}-\mathrm{Au}-(\mathrm{U})$ hydrothermal activity and $\mathrm{Nd}$ isotope constraints on metal sources in the Gawler Craton, South Australia: Economic Geology and the Bulletin of the Society of Economic Geologists, v. 102, p. 1441-1470, doi:10.2113/gsecongeo.102.8.1441.

Zhao, J.-X., and McCulloch, M.T., 1993, Sm-Nd mineral isochron ages of Late Proterozoic dyke swarms in Australia: Evidence for two distinct events of mafic magmatism and crustal extension: Chemical Geology, v. 109, p. 341-354, doi:10.1016/0009-2541(93)90079-X.

Manuscript received 29 November 2010

Revised manuscript received 24 March 2011

Manuscript accepted 28 March 2011

Printed in USA 